\title{
THE HORSE SOLDIERS
}

\section{Lessons from expeditionary unconventional warfare}

\author{
Mark E. Mitchell
}

At 9:59 AM on September 11, 2001, as the soldiers of the U.S. Army's 5th Special Forces Group watched the stunning and unforgettable collapse of the South Tower of the World Trade Center, they knew instinctively that their lives would soon change dramatically. As the Army Special Forces group designated to support U.S. Central Command (CENTCOM) - the geographic combatant command with an area of responsibility stretching from Egypt to Pakistan - they would surely be involved in any response to the terrorist attacks. President George W. Bush pledged to "find those responsible" for the most devastating attack against the United States since Pearl Harbor and "bring them to justice."1

In the weeks following the attacks, the 5th Group began deploying to Uzbekistan to serve as the vanguard for America's response to these horrific events. On the night of October 19, 2001, with support from the 160th Special Operations Aviation Regiment and U.S. Air Force Special Operations aircraft, the first Special Forces Operational Detachment Alphas (ODAs), or detachments, infiltrated Afghanistan and linked up with Afghan resistance forces and elements from the Central Intelligence Agency (CIA).

A mere 102 days after the 9/11 attacks, the Taliban and their al-Qaida "guests"-including Usama bin Ladin and hundreds of his supporters - had been routed by a motley collection of tribally and ethnically based resistance forces supported by U.S. Special Operations Forces (SOF) and coalition air power. The Afghan Interim Administration assumed power in Kabul, while the men and women of Task Force Dagger - a joint task force built around the 5th Special Forces Group and commanded by the group commander, Colonel John Mulholland-celebrated a hard-fought victory whose swiftness defied all predictions. $^{2}$

The stunning success of the Afghan resistance forces-who on September 10, 2001, had been near collapse-was enabled by an international effort spearheaded by the CIA and SOF supported by U.S. airpower. The combination of lethal aid supplied by the CIA and the precision airstrikes directed by SOF stunned the Taliban and sent them into headlong retreat. Major cities fell to the Northern Alliance and other resistance forces in rapid succession. The image of U.S. soldiers, airmen, and intelligence officers riding on horseback with their Afghan partners rapidly became the iconic picture of this initial phase of the long war in Afghanistan. ${ }^{3}$

The achievement of this in-extremis effort was widely and rightly celebrated. A few hundred Americans on the ground in Afghanistan helped indigenous forces vanquish a mutual enemy and pursue a hated foe who had killed nearly 3,000 Americans, inflicted serious damage to the U.S. economy, and dealt a blow to America's sense of security. ${ }^{4}$ From afar, the rapid if imperfect ${ }^{5}$ success of this operation made it 
seem almost effortless and preordained. The reality, especially for those on the ground in Afghanistan, was decidedly different.

This chapter describes the author's experience conducting unconventional warfare in the aftermath of $9 / 11$. It starts with a brief overview of unconventional warfare, how the U.S. Army drifted away from it, and the strategic focus of the United States prior to 9/11. Next, it describes the author's experience planning, infiltrating, and fighting with the Northern Alliance to defeat Taliban and al-Qaida forces near Mazar-i-Sharif in northern Afghanistan. Finally, it provides some lessons for unconventional warfare operations.

\section{Army Special Forces and unconventional warfare}

Since its inception, a core activity of U.S. Army Special Forces has been unconventional warfare, defined as "activities conducted to enable a resistance movement or insurgency to coerce, disrupt, or overthrow a government or occupying power by operating through or with an underground, auxiliary, or guerrilla force in a denied area." ${ }^{\prime}$ Although the doctrinal definition has changed over several decades, ${ }^{7}$ the essential components have remained the same: enabling an indigenous movement in a denied area to coerce or overthrow an established government or occupying power. The doctrine, organization, training, and equipment of the Special Forces are all designed to ensure that detachments can successfully execute this mission anywhere in the world.

Every prospective Green Beret ${ }^{8}$ must first pass a rigorous assessment and selection course before training begins. They then must complete the Special Forces Qualification Course, language training, and special skills $^{9}$ training before assignment to an operational group. The training, which can take up to two years, produces a disciplined, mature, and highly capable Special Forces soldier.

The capstone exercise of the qualification course is known as Robin Sage. This unique two-week exercise replicates an unconventional warfare environment. ${ }^{10}$ It is remarkably effective in preparing Special Forces soldiers for the challenges they may soon face. Nevertheless, the Department of Defense, CENTCOM, and the 5th Group were still unprepared for unconventional warfare in Afghanistan, because the demand for it was practically non-existent prior to $9 / 11$. In seeking to understand why, it is necessary to review the preceding decades and the strategic forces that shaped the mission focus.

\section{Drifting away from unconventional warfare}

U.S. Special Forces trace their lineage to multiple organizations from World War II: the 1st Special Service Force, Merrill's Marauders, and the Office of Strategic Services. In June 1952, the first Special Forces group, the 10th Group, was activated. It focused on preparing for guerrilla warfare behind enemy lines in the event of a Soviet invasion of Western Europe. By 1957, additional Special Forces began training Vietnamese Army commandos. ${ }^{11}$

Their role later shifted to advising irregular forces and supporting counterinsurgency missions. By the time they were withdrawn from Vietnam in 1971, the Special Forces had achieved significant success on the battlefield and a level of notoriety in popular culture. ${ }^{12}$

Nevertheless, their fortunes declined precipitously for the next decade. The U.S. Army deactivated several Special Forces groups, and attention quickly turned from counterinsurgency and irregular warfare to focus on the Soviet threat in Europe. During the 1980s, small numbers of Special Forces deployed to El Salvador to assist the government in combating a socialist insurgency. Special Forces also participated in counternarcotics efforts in South and Central America in the 1980s and the invasion of Panama in 1989.

In 1990, the Pentagon reactivated the 3rd Special Forces Group. In 1990-1991, the 5th Group played a critical role in the operations Desert Shield and Desert Storm: monitoring Saudi Arabia's border, conducting deep reconnaissance in Iraq, and acting as liaisons with Arab forces in the U.S.-led coalition. ${ }^{13}$ 
Following the liberation of Kuwait from Saddam Hussein's Iraq, the 5th Group assumed a permanent, rotational presence in Kuwait, advising and training the Kuwaiti Army.

Additionally, the 10th Group supported humanitarian relief operations in Turkey and northern Iraq after the conclusion of the Gulf War. ${ }^{14}$ Special Forces elements also supported United Nations peacekeeping operations in Somalia and Haiti and the implementation of the Dayton Accords following the civil war in Bosnia-Herzegovina. ${ }^{15}$

In short, for nearly five decades after their establishment, Special Forces units participated in just about every type of operation imaginable, except bona fide unconventional warfare. Instead, Special Forces performed foreign internal defense and an array of ancillary missions. The unique skills of the Special Forces soldier were in high demand, and the budget and size of the Special Forces grew substantially throughout the 1990s. Nevertheless, demand for Special Forces to conduct unconventional warfare did not exist.

The dearth of unconventional warfare missions was not due to the absence of opportunities. The United States provided significant support to Afghan tribesmen in their efforts to drive Soviet forces from their country in the 1980s under President Ronald Reagan, but this was accomplished through a successful covert action program run by the CIA. Special Forces played a minor supporting role, at best.

Even as the threat from al-Qaida in Afghanistan grew in the late 1990s, the Department of Defense and the executive branch were reluctant to employ Special Forces to overthrow the Taliban. ${ }^{16}$ A variety of factors contributed to the aversion of using Special Forces to conduct their core mission: concern over risk (strategic, political, tactical), especially after the October 1993 debacle in Mogadishu; a paucity of political will; and the existence of similar capabilities in the intelligence community.

These factors also influenced a perception among some in the Special Forces and the larger special operations community that the United States would never again engage in unconventional warfare. This perception had real consequences. Although training in the qualification course was inextricably linked to unconventional warfare, there was little emphasis on it in the Special Forces groups and no interest whatsoever in the rest of the Department of Defense or the U.S. government.

\section{Strategic focus}

The last decade of the 20th century marked the end of the Cold War. In a span of less than two years, Germany reunified, the Soviet Union collapsed, and the Warsaw Pact dissolved. Discussion focused on how to invest the anticipated "peace dividend" in this new, peaceful era. President Bill Clinton's National Security Strategy in December 2000 focused on adapting Cold War alliances, engaging with former adversaries, advancing democracy and human rights, and promoting economic prosperity. ${ }^{17}$ The strategy mentioned Afghanistan in the context of abuses of religious freedom, illegal drug trafficking, and sheltering Bin Ladin and other terrorists, but the response focused on "energetic diplomatic efforts" rather than military options. ${ }^{18}$

Simply put, the U.S. government did not envision any possibility of military action in Afghanistan to overthrow the Taliban. The 5th Special Forces Group had trained in Pakistan, Uzbekistan, and Tajikistan, but Afghanistan was the one country in the region where it never expected to operate. The Soviets and the British before them had invaded Afghanistan with massive, well-equipped forces only to later withdraw from the "graveyard of empires" after ignominious years of casualties and calamities. The United States had no intention of ever getting directly involved in the country.

As a result, CENTCOM had no contingency plans for operations in Afghanistan on 9/11. The 5th Group had soldiers trained in Arabic, Farsi, and even in Urdu, but none specifically trained in Pashto or Dari, the dominant languages in Afghanistan. Also, few were trained on the employment of horses and pack animals. Few could identify any of the major political figures in the Taliban, resistance groups, or specific tribes. The average soldier knew little about Afghan culture or history. No one in the 5th Group had any personal relationships with anyone of importance in Afghanistan. 
Yet by mid-morning on 9/11, the impossible had become the inevitable, and the 5th Special Forces Group - and the rest of the U.S. national security apparatus - began an urgent effort to prepare.

\section{Horse soldiers}

In 1998, President Clinton ordered Tomahawk cruise missile strikes against al-Qaida training camps in Afghanistan, but air power alone could not drive the Taliban and al-Qaida from Afghanistan. ${ }^{19}$ After the 9/11 attacks, it was immediately clear to the 5th Group soldiers that any response to the attacks would involve Army Special Forces. Although ignorant of the specifics on the ground in Afghanistan, the group understood the strategic situation in the region.

\section{Planning}

The United States had no conventional forces deployed in Central Asia. Moreover, the United States did not have permanent military bases in any of Afghanistan's neighboring countries from which it could launch and sustain a conventional campaign. Establishing such bases and deploying conventional forces would take months. Even then, the mountainous terrain posed a substantial challenge.

Additionally, Afghanistan was landlocked, with the nearest seaport hundreds of kilometers away in Karachi, Pakistan. Given Pakistan's sponsorship of the Taliban and the population's deep distrust of the United States, it was clear that Pakistan would not allow the basing of U.S. military forces to strike the Taliban and their al-Qaida guests.

Planning for operations in Afghanistan began immediately and unfolded simultaneously at the strategic, operational, and tactical levels. At the strategic level, the United States made futile overtures to the Taliban government to apprehend and turn over Bin Ladin while also negotiating with surrounding countries for staging, basing, and overflight rights and permissions to launch attacks on a neighboring country. ${ }^{20}$ For a variety of reasons, diplomatic efforts focused on Uzbekistan, which granted access to Karshi-Khanabad ("K2"), an old Soviet airfield in southern Uzbekistan-but only for search and rescue operations.

At the operational level, CENTCOM, under the command of General Tommy Franks, was designated as the "supported command" for all operations. Within days, planners from other defense organizations and government agencies descended on the CENTCOM headquarters and its subordinate headquarters, Special Operations Command Central (SOCCENT), both at MacDill Air Force Base in Tampa, Florida.

At the tactical level, the 5th Special Forces Group struggled with the implications of being designated the core of Joint Special Operations Task Force-North (JSOTF-N), which later came to be known as Task Force Dagger. Per the joint and Army doctrine in effect at the time, the 5th Group would have normally been designated as an Army Special Operations Task Force, while SOCCENT would function as the JSOTF, controlling all SOF in the Afghanistan theater. ${ }^{21}$

SOCCENT Commander Rear Admiral Bert Calland, however, eschewed this role, preferring instead to retain control of all SOF in the CENTCOM area of responsibility. In an interview with an Army historian, Calland defended this decision by pointing to his other responsibilities across the CENTCOM area of responsibility, stating, "My job is [CENTCOM] wide." 22

Although the actual plan was still under development, the 5th Group placed four detachments in "isolation"- a strictly controlled planning environment designed to ensure operational security - to begin familiarizing themselves with Afghanistan. ${ }^{23}$ Issues developed almost immediately at every level. The peacetime staffs at SOCCENT and 5th Group were insufficiently manned or untrained to perform many of the joint functions that the mission demanded. Each staff required substantial augmentation and training about joint staff procedures.

New personnel ("augmentees") had to be identified, integrated, and trained at the same time that these already stretched staffs planned and directed combat operations. Additionally, the equipment on 
hand - especially critical communications systems like local area networks — was inadequate for the assigned missions. Worse, the various headquarters competed against each other for these limited resources.

The detachments in isolation at Fort Campbell, Kentucky, quickly discovered that the United States lacked military maps of Afghanistan. Luckily, they were able to obtain Soviet-era maps to support their planning. They also discovered that many detachment members lacked the Top Secret clearances needed to access some of the information concerning potential operations.

The detachment planning also exposed another serious deficiency: a lack of leadership profiles. In a classic unconventional warfare scenario, a "pilot team" would link up with and assess the resistance movement's leaders and overall readiness. This information would be gathered in a dossier passed on to the detachments during isolation so that they could conduct detailed planning. But pilot teams and dossiers for resistance leaders whom they would most likely advise- Mohammed Fahim Khan and Abdul Rashid Dostum-did not exist. They would have to rely on CIA intelligence officers to introduce them and on their Robin Sage training to carry them forward.

The staffs and detachments also recognized that standard military-issued equipment might not be suitable for the environment in Afghanistan, which set off a mad scramble to procure needed items from stores such as REI, Bass Pro Shop, and other specialty outfitters. It was only the first of many logistical problems that the detachments would encounter in the early days of Operation Enduring Freedom.

\section{Organizing for combat}

As planning furiously continued, an advance party deployed to Uzbekistan's K2 airbase in late September 2001 to begin the assessments and coordination necessary to receive additional forces. Soon afterward, other forces began to move to K2 in accordance with a hastily developed deployment plan, but ongoing negotiations and a lethargic Uzbek bureaucracy stalled their arrival. This caused a significant backlog of C-17 aircraft at airfields across Europe. At this point, Secretary of Defense Donald Rumsfeld personally intervened and on October 5, 2001, received permission from Islam Karimov, the president of Uzbekistan, to use $\mathrm{K} 2$ for search and rescue operations. ${ }^{24}$

On October 6, C-17s began arriving at K2 approximately every two hours. Over the course of the next week, the American population at the base swelled from 100 to more than 2,000. The following day, Operation Enduring Freedom officially began with airstrikes on key Taliban targets across Afghanistan. ${ }^{25}$

Twelve days later, on October 19, the first U.S. forces set foot on the ground in Afghanistan. ${ }^{26}$ Other U.S. SOF conducted an airborne assault on an airstrip outside Kandahar and an airmobile assault on the compound of Mullah Muhammad Omar, the elusive Taliban leader, in Kandahar, while helicopters from the 160th Special Operations Aviation Regiment inserted two 5th Group ODAs (595 and 555) in the mountains of northern Afghanistan to link up with Khan and Dostum. ${ }^{27}$

The former Soviet airbase may have been ideal in terms of geographic proximity, but it was deeply flawed in many ways. Littered with abandoned Soviet equipment, trash dumps, contaminated soil, and an absence of functional latrines, it made for squalid living conditions. The constant stream of personnel, aircraft, equipment, and supplies from multiple units, headquarters, and services made it chaotic. The limited space and poorly defined command relationships between the Air Force and Army personnel at the base also added to the confusion.

Ultimately, the Air Force Joint Special Operations Aviation Component responsible for the combat search and rescue mission merged into the JSOTF-N commanded by Mulholland. This unique, nondoctrinal arrangement set off another round of headquarters and staff integration and adaptation on the fly.

I arrived at K2 on the night of October 26, 2001. As the operations officer for 5th Group's 3rd battalion, I had been tasked to establish the tactical operations center for an Army Special Operations Task Force. Within minutes of my arrival, however, I was directed to report to the isolation facility for planning. I discovered that Mulholland had decided to insert his battalion commanders as liaisons to the senior resistance 
commanders. My commander, Lieutenant Colonel Max Bowers, had been assigned to assist Dostum and provide command and control for detachments operating with Northern Alliance forces in the vicinity of the Darya Suf Valley.

Bowers had assembled an ad hoc team-including me and a Special Forces communications sergeantto accompany him. We were designated as Special Forces Operational Detachment Charlie (ODC) 53. Three of the other team members came from the battalion's Bravo Company. Since I had commanded the company until June 2001, I was intimately familiar with them. The last two members of our team were two U.S. Air Force Joint Terminal Attack Controllers to control aircraft essential to the mission. They were highly trained and competent patriots, but none of us had ever met, trained, or operated with them. It was, to say the least, a highly unusual situation.

The decision to send battalion commanders "into the box," ostensibly to provide more senior advisors, had several important consequences.

First, although the ODC had been part of Special Forces doctrine in the Vietnam era, it was no longer part of our doctrine. We simply were not organized or equipped for the mission, and, more importantly, we had never trained specifically for it. Now, with an ad hoc and hastily assembled "team," we prepared to go deep into Afghanistan to wage unconventional warfare against the Taliban.

Second, it disrupted the task organization of the battalion headquarters and one of the company headquarters; it left the battalion executive officer in command and split up a company headquarters. Large portions of the battalion staff were then conscripted as augmentees to the JSOTF.

Third, it altered the entire command and control structure. Lieutenant colonels on the ground with limited communications and focused on advising an Afghan commander were in no position to exercise command and control; the environment was too fluid and dynamic. Instead, the ODAs and ODCs ended up reporting directly to Task Force Dagger in contrast to doctrine that called for two intermediate headquarters between the ODAs and the JSOTF. Mulholland, through his fledgling JSOTF staff, now had a large and growing span of control.

This had a tertiary effect on an already stretched logistical system. Typically, the company and battalion headquarters would handle the logistics support for the detachments. Dedicated teams of individuals familiar with each detachment and their mission, known as area support teams, were supposed to shepherd the detachments' resupply requests. In conjunction with the battalion staff, they would build and inspect resupply bundles to ensure the teams had what they needed.

Unfortunately, most of the logistics support came from Incirlik, Turkey, under the command of Special Operations Command Europe, and there were no area support teams there to assist. The combination of untested staffs, extremely long supply lines, and poor communications would lead to a high number of unfilled requests and immense frustration.

Irrespective of the unusual situation, everyone on ODC 53 recognized the importance of the mission and diligently attempted detailed mission planning. Much like the other teams, there was a great deal of information that the ODC lacked, so assumptions and contingency plans had to be made. After several days of planning and preparation, the ODC was ready to go.

\section{Infiltration and planning with the Northern Alliance}

The harsh and unpredictable weather in the Hindu Kush Mountains posed a significant challenge for infiltration. The conditions limited the amount of cargo the MH-47E helicopters could carry, and we had to abandon a plan to take a small pickup truck for mobility. In its place, the ODC requested two John Deere "Gators," six-wheeled all-terrain vehicles, from an infantry battalion of the 10th Mountain Division that provided base security at K2. They obliged.

The weather also caused multiple delays. For three consecutive nights, the ODC loaded onto helicopters with engines running only to disembark two hours later. At one point, Task Force Dagger's energetic 
executive officer came up with a plan to conduct an airborne infiltration using "rough terrain suits" on a short, narrow drop zone on a mountain plateau.

Typically, only Army airborne engineer units use rough terrain suits. These heavily padded canvas suits, with a helmet resembling those worn by National Football League linebackers, were designed to allow the engineers to jump in wooded terrain to clear landing zones. None of us were confident that they would protect us if we missed the landing zone and tumbled down the mountain. Moreover, none of the team had ever parachuted with one. The idea was quickly abandoned, and luckily the weather cleared enough on the night of November 2 to complete the infiltration.

ODC 53 infiltrated using MH-47 helicopters. The flight to Landing Zone Burro-which included aerial refueling, low-level "nap-of-the-earth" flying, and a false insertion-took three and a half hours. Dostum would later tell us that his forces had alerted him to helicopters long before we arrived.

Landing Zone Burro was a relatively small but level area along the Darya Suf River, approximately 120 kilometers south of Mazar-i-Sharif. The ethnic Uzbek militia of Dostum's Junbesh-i-Milli political party had sought refuge in these mountains after the Taliban seized control of Mazar-i-Sharif in 1998. Three years in this wilderness had taken its toll, and they were in dire need of assistance.

Our pulses quickened as the helicopters set down on Landing Zone Burro. Even though we knew that ODA 595 and CIA officers would be there to meet us, we were unsure of what to expect. It was around 3 AM local time. The moon had set, and the remote valley was devoid of electricity or ambient light. As we began to off-load our extremely heavy rucks (military backpacks), hands reached out of the total blackness and grabbed them.

Due to the darkness, the roar of the engines, and the rotor wash, we could not see the faces of those grabbing our gear, but we continued to offload. After about a minute on the ground, the helicopters departed into the darkness. To our relief, we soon discovered that a couple of the helping hands belonged to members of ODA 595.

Dostum was asleep, and we all agreed that there was no need to wake him. During the Afghan Civil War, Dostum had gained a reputation as a ruthless warlord, and we did not know what to expect. Unverified stories of his cold-blooded deeds and perfidy seemed to dominate what little information we received before infiltration. It was difficult to sort fact from fiction. Yet ODA 595 had been on the ground with Dostum for two weeks and had suffered no harm. In fact, ODA 595 found that Dostum had been especially protective of them, fearing that any harm to the Americans would destroy his relationship with the United States and his opportunity to defeat the Taliban.

After receiving a detailed update on the situation, we established security and initiated our sleep plan. We met Dostum later that morning and began efforts to build rapport. It was a complex task, since ODA 595 had already been on the ground with Dostum for two weeks, earning his trust, confidence, and a certain fondness. He was reluctant to see that bond broken and remained closer to the ODA 595 commander than any other American.

My initial impression was that while Dostum was deadly serious about defeating the Taliban, he was also gregarious, with a quick wit and sense of humor. Standing well over six feet tall, he seemed a giant in comparison to his subordinates and rode a white stallion that was also much larger than the other horses. In conversation through translators, he came across as intelligent and insightful, even if not particularly well educated.

At any rate, he had earned the respect and loyalty of his forces and the affinity of ODA 595. The feelings were mutual, and he seemed perturbed that a new group of Americans now imposed themselves on their happy marriage. He insisted on keeping the detachment commander at his side and only reluctantly accepted ODC 53. His indifferent attitude toward ODC 53 would have real consequences later during the offensive up the Darya Suf Valley.

The local portion of the Northern Alliance comprised Uzbek forces under Dostum, Tajiks under Mohammed Atta, and Hazaras under Haji Mohaqqeq. They were united by a shared hatred of the Taliban, 


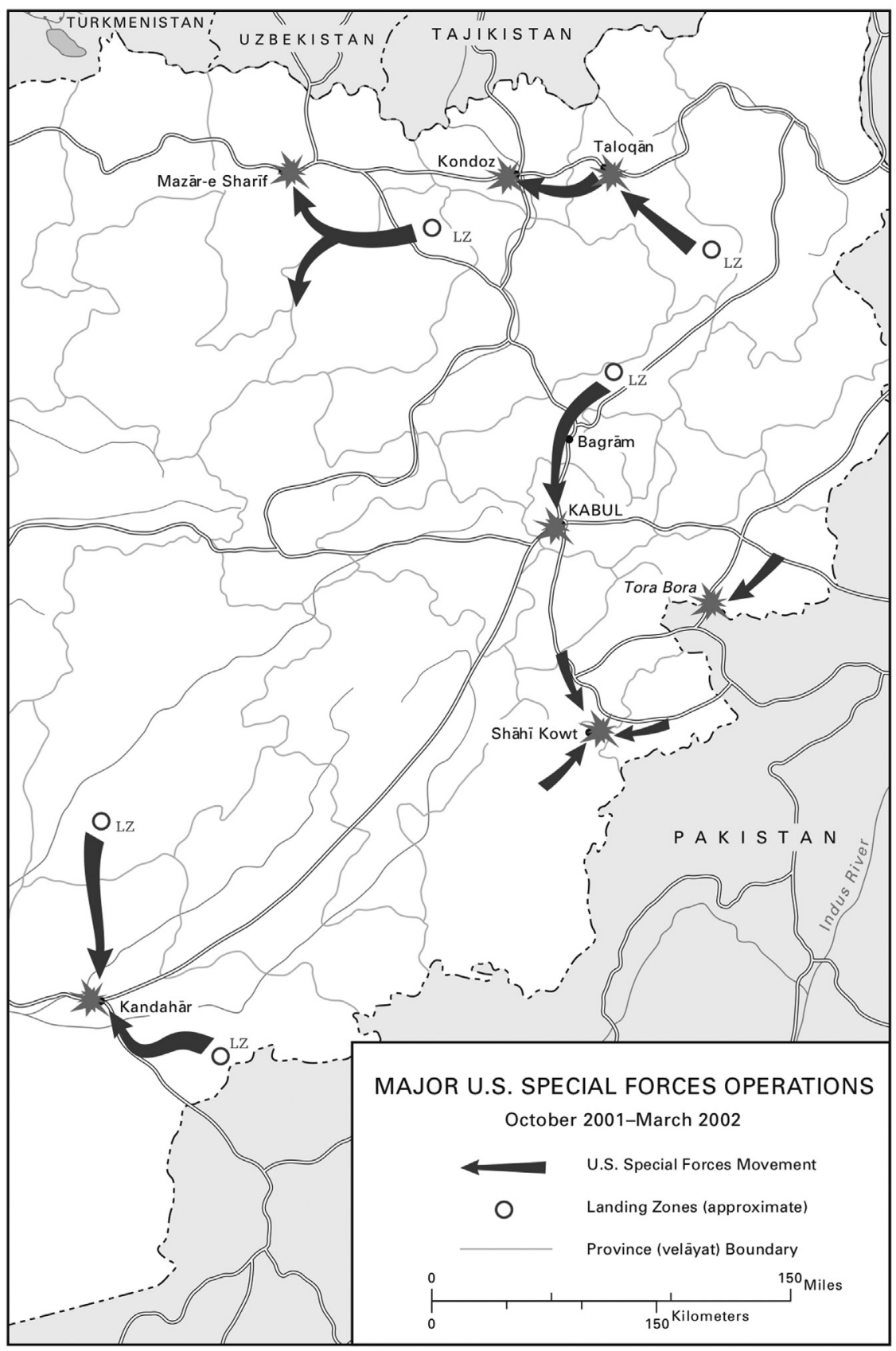

Figure 17.1 Major U.S. Special Forces operations in Afghanistan, 2001-2002. ${ }^{28}$

Source: This map appears in Operation Enduring Freedom (Washington: Center of Military History, no date), 9, retrieved from https://history.army.mil/html/books/070/70-83/cmhPub_70-83.pdf. 
but little else, and were already planning a major offensive to recapture the strategically important city of Mazar-i-Sharif. A detachment provided advice and assistance to each faction. ODC 53 was responsible for coordinating and synchronizing the detachments and the Northern Alliance forces and deconflicting the U.S. airpower essential to their success.

We spent the next several days near Landing Zone Burro establishing rapport, which included providing medical treatment to Afghans who had been wounded in battle. We also conducted battlefield reconnaissance on horseback and coordinated for delivery of small arms and ammunition, as well as blankets, horse feed, and cold weather clothing and gear.

Dostum was frustrated and anxious with the pace of support. General Franks had personally promised aid, but it had yet to arrive. Dostum's forces were desperately short of arms and ammunition, and their ability to launch an offensive was contingent on receiving enough supplies to carry them to Mazar-i-Sharif.

Dostum asked us directly, "Why does [General Franks] promise things he can't deliver?" Franks, however, did not share the same sense of urgency, because CENTCOM was operating on a much different timeline. The initial plan envisioned Special Forces training and equipping the Northern Alliance during the winter months and conducting a coordinated offensive in the spring. Dostum, however, was ready to launch the offensive now.

Another fact that Dostum did not fully grasp was that the Department of Defense did not have stocks of weapons and ammunition to provide to indigenous forces. It did not matter that a core part of the Special Forces' unconventional warfare mission specified equipping and training indigenous forces. The U.S. military had neither the Congressional authorization nor funding to purchase and maintain weapons stockpiles for use by foreign irregular forces.

Our team did not fully understand this reality, either. In training, we used the Army's communications standard operating procedures, which included codes for prepackaged sets of weapons and ammunition, ${ }^{29}$ and we assumed that there were warehouses with stockpiles from which these prepackaged sets would be drawn. But these stockpiles, as well as backup equipment for our own gear, did not exist. As a result, we had to rely on the CIA to provide necessary aid. Our backup equipment was stripped from units not committed to the fight.

Ultimately, Dostum's initial aid was delivered on November 4. Unfortunately, not one of the 20 bundles landed on the drop zone (the same small area associated with the rough terrain suits). Wind blew many of the bundles over the side of the rugged cliffs. Some of the bundles came crashing down very close to our encampment, sending us scrambling into the caves where we had been living. Other bundles ended up suspended on the cliffs when the parachutes snagged on the rocks.

Using the John Deere Gators, ODA 595 and a coterie of Afghans retrieved what they could in the darkness, and retrieved some, but not all, of the suspended bundles the following day. In a typical snafu, the cold-weather clothing and boots came in a range of sizes typical for an average American unit, but not a typical Afghan militia. The average Afghan was of slighter stature, and the clothing and boots were generally too large. Thus, it was not uncommon to see an Afghan wearing a Gortex parka that went down to his knees.

Planning and executing a synchronized offensive by three independent and geographically dispersed militias from multiple avenues of approach is a difficult task under any conditions. It was made even more difficult by the arduous mountains, poor communications, and language barrier.

For communications with Task Force Dagger, we relied principally on data burst transmissions using a high-frequency radio. We had satellite phones and a satellite communications radio for voice communications, but the phone was unreliable, and the radio could only be used from a stationary location. For intrateam communications, we used secure FM radios, although the terrain limited their range. There were long periods of time when we had no direct communications with anyone but our Afghan counterparts. 
With the assistance of intelligence officers and a handful of Afghans who spoke English, the ODAs and ODC 53 assisted the Northern Alliance in developing a reasonably coherent plan to retake Mazar-i-Sharif. If successful, it would set the stage for liberating all of northern Afghanistan from the Taliban.

During planning, Dostum requested additional aid and "true" close air support. As a countermeasure against man-portable air defense systems, U.S. aircraft could not fly lower than 15,000 feet above ground level. Dostum, a former general in the Afghan army, believed it was necessary to fly lower to hit smaller and rapidly dispersing Taliban forces. He also wanted close air support continuously available on short notice to take advantage of fleeting opportunities. Neither request was granted, but Dostum did receive some additional air support for the offensive to seize Mazar-i-Sharif.

The offensive on Mazar-i-Sharif began on November 5, with the delivery of two BLU-82 15,000 pound conventional bombs, known as the "Daisy Cutter," by a special operations MC-130 aircraft. Originally designed to clear jungle landing zones in Vietnam, we chose to use this unguided weapon mainly for its psychological effect. With Dostum's input, we selected a previously abandoned village that the Taliban had occupied. Yet out of a misplaced concern for civilian casualties where there were no civilians, the target was moved to an open area several kilometers from the original target. If it had any effect on the Taliban, it was not discernable.

The offensive immediately encountered stiff resistance from Taliban forces reinforced by al-Qaida volunteers. Eventually, ODA 595 successfully directed precision airstrikes on Taliban positions, allowing Northern Alliance forces to break through the initial resistance. Every U.S. soldier and airman, except for a handful using the John Deere Gators, received horses to ride during the offensive. There were no "extra" horses available, so for each horse ridden by an American, an Afghan soldier had to walk.

The saddles were made of wood with remnants of Oriental rugs tacked on for "cushioning." As hard as the saddles were on us, they could be much harsher on the horses, which were not accustomed to bearing American soldiers loaded with our individual gear, such as radios, batteries, ammunition, and water.

The stirrups on the saddles were also too small for our large boots, making it difficult to firmly position our feet in the stirrups. We had to learn how to jam the toe of our boots into the stirrups while mounted. An experienced horseman on ODA 595 had requested proper saddles for the horses, but due to the extended and chaotic logistical support, the saddles would not arrive until long after we had liberated Mazar-i-Sharif and transitioned to vehicles.

For the most part, we had little, if any, experience riding horses, especially in the rugged mountains of Afghanistan. We had to learn and adapt quickly if we wanted to keep up with our experienced hosts. The Afghans navigated these trails not by maps but by memory. They had difficulty describing our destinations, so we had to follow them. Once the offensive began, we would ride for hours at a time, sometimes up to 10 hours, along narrow and winding mountain trails.

Some of the night rides were especially harrowing as we traversed trails on the edge of deep canyons. The canyons were so deep at times that we could not see the bottom even with our night vision goggles. Rest halts could be troublesome as well. Due to the complete lack of ambient light, upon which our night vision depended, it was difficult to see when the group began moving again. We experienced multiple "breaks in contact" during our rides, but we miraculously always managed to link up again.

\section{Combat offensive to seize Mazar-i-Sharif}

With ODA 595 directing effective airstrikes on Taliban positions, the offensive managed to reach its designated objectives on the first day but encountered more heavy resistance at the final objective: the village of Boi Becha. With an effective defense employing well-placed machine guns, the sizeable Taliban force repelled several assaults by Dostum's forces. 
In a last-ditch effort to seize the critical terrain on which the village sat, Dostum massed nearly 1,000 mounted riflemen in three ranks behind a small ridge not far from the village. On command, the three ranks lurched forward and moved over the ridge. As they cleared the ridge, they charged the village, breaking into a full gallop and firing their rifles at the Taliban positions. They routed the Taliban, with survivors fleeing further up the valley. We had witnessed the first cavalry charge of the 21 st century.

Fighting continued in the Darya Suf Valley for five more days. Despite some fierce resistance, the Northern Alliance troops, flush with new arms and ammunition and energized by the effectiveness of American airpower, steadily drove the Taliban and their al-Qaida allies northward. Whenever we stopped, Dostum's staff would pull out a 12-volt car battery and a citizens band radio that the general would use to contact the Taliban and supporting militia leaders. In a typical Afghan scheme, Dostum skillfully used the threat of American airstrikes to cut deals with some militia leaders allied with the Taliban. As his forces neared, some of these militias abandoned the Taliban and switched sides.

At one point during the drive to Mazar-i-Sharif, irritation with the ODC 53 commander turned Dostum's indifference to enmity. While stopped for several hours at one of their mountain redoubts, Dostum was apparently insulted by the tone and content of the advice he received from the commander. He advised us that he was going on a reconnaissance mission with members of ODA 595 and needed our horses. He left us with an interpreter and vowed to send the horses back to us in a few hours. Thirty-six hours later, it was abundantly clear that the horses would not be returning; he had abandoned us on the mountaintop. A pointed discussion with our interpreter confirmed our suspicions: it was a deliberate decision by Dostum. We were now on our own.

With the reluctant help of our interpreter, we rented local burros using $\$ 100$ bills. We had carried tens of thousands of dollars in cash, called an "operational fund," for just such an emergency. We used the burro to carry our gear off the mountaintop and set out to regroup, hopefully with friendly forces. The night was pitch black, and once again our night vision goggles were of limited utility. We followed a heavily rutted trail that we hoped would lead us to the valley below. During the march, one of the burros stumbled in a rut and ended up on its back unable to move due to the weight of our gear. It was hard not to laugh at the plight of this unfortunate animal, but we unstrapped the hapless and frustrated beast, got it back on its feet, remounted all the gear, and moved out again.

Passing quietly through several unmarked villages, so as not to provoke gunfire from frightened residents, we eventually reached the river valley. With the moon now lighting the sky, we crossed to the road on the east side of the river and began marching northward. We were fortunate enough to find a group of Hazara militia waiting for transportation to the front lines. After several hours, a convoy of jinga ${ }^{30}$ trucks arrived, and we piled into the back with what seemed to be 100 Hazaras.

Just after dawn, we reached the town of Shulgera where Dostum had halted his advance and linked up with ODA 595 and the CIA officers-almost two full days since we had last seen them. If Dostum was surprised to see us, he never let it show, and we continued as if nothing had happened.

On November 10, the Northern Alliance forces seized control of the gateway to Mazar-i-Sharif, the Tangi Gap. Beyond this gap lay open plains to the city of Mazar-i-Sharif, a mere 30 kilometers away by road. The battle for the gap was not without cost. The Taliban had heavily mined the gap, which led to the deaths of numerous Northern Alliance soldiers and horses, as well as destroyed vehicles. In the small villages along the road to Mazar-i-Sharif, thankful crowds lined the road and cheered on the Northern Alliance as they pursued fleeing Taliban into the heart of Mazar-i-Sharif.

A contingent of nearly 200 Taliban and al-Qaida fighters seized the Sultan Razia Girls School in the heart of Mazar-i-Sharif, where they chose to make a stand. Located only one-quarter mile from the famed Blue Mosque at the center of the city, the multistory building provided a good vantage point for the Taliban defenders. ODA 595's request for airstrikes on the school caused significant concern at Task Force Dagger, which worried about civilian casualties in the surrounding areas and the possibility of 
damaging the Blue Mosque. Given the exigency of the circumstances, ODA 595 received permission and carried out a series of airstrikes around the school before the Northern Alliance routed the remaining Taliban.

Once in Mazar-i-Sharif, we moved to Qala-i-Jangi, an 18th-century British mud fortress about 5 kilometers southwest of the city. The fortress had served as Dostum's headquarters until the Taliban seized control in 1998. It was stocked with all manner of arms and munitions, including cases of World War I-era bayonets for the 1903 version of the Springfield rifle. The security situation in the city was still tenuous as Taliban sympathizers went into hiding.

The unsteady alliance of Uzbeks, Tajiks, and Hazaras started to show strains almost immediately as the factions staked out territory and competed for post-conflict influence and control. After two weeks at the fortress, the commander of ODC 53 decided to establish an independent U.S. compound on the east side of the city, much nearer to the airfield that would become essential to continued operations. We occupied the Turkish School, a five-story concrete building surrounded by a 10 -foot wall.

Although the Northern Alliance now controlled Mazar-i-Sharif, the Taliban was reportedly massing forces for a counteroffensive in the city of Kunduz, 170 kilometers east of Mazar-i-Sharif. As Northern Alliance forces began to move eastward, they encountered a convoy of trucks with approximately 600 Taliban and foreign al-Qaida fighters. After a standoff and negotiations, which included a suicide bomber that killed Dostum's intelligence chief, the group surrendered. A small force, consisting of soldiers who were not fit to fight at Kunduz, escorted the trucks to Qala-i-Jangi. But they failed to search the trucks or prisoners because they "had given their word" that they would no longer fight.

The next day, using smuggled weapons, the prisoners staged an uprising, killing CIA officer Mike Spann and seizing control of the fortress, including its stockpile of weapons. ${ }^{31}$ An unknown number of prisoners escaped into the surrounding area, and local villagers captured and killed some of those fleeing. The large majority, however, remained in the fortress, and a three-day battle ensued with members of ODC 53 directing "danger-close" airstrikes with 2,000-pound guided bombs and AC-130 gunships against the former prisoners.

One bomb mistakenly struck a U.S. position, wounding five Americans and four members of a United Kingdom Special Boat Service detachment that had arrived the prior day. The errant strike also killed several Afghans and destroyed a T-55 tank, but all of the Americans and Brits survived. ${ }^{32}$

The battle concluded when the survivors, who had barred themselves in the basement of a building, were forced out after Dostum's men flooded the basement with water. Of the original 600 prisoners, only 85 survived. Among the survivors was Johnny Walker Lindh, an American convert to Islam who had made his way into Afghanistan via Yemen and Pakistan. He was not discovered until several days after the battle, but was eventually returned to the United States, convicted in federal court of providing support to terrorists, and sentenced to 20 years in prison. ${ }^{33}$

After the battle, our attention turned to re-opening the Mazar-i-Sharif airport, which had been heavily damaged by the U.S. Air Force during the opening salvos of the war. Five large craters, each about 30-40 feet wide and 15-20 feet deep, were neatly spaced down the length of the runway and, for good measure, another four bombs created a single large crater that ran perpendicular to the runway. Hazardous munitions also littered the airport.

The road to Uzbekistan, however, was heavily mined and would take months to clear. With the onset of winter, the internally displaced persons living in squalid camps around Mazar-i-Sharif faced not only the harsh weather but also starvation. The only way to move enough relief supplies to Mazar-i-Sharif was by air, and Task Force Dagger ordered that we repair the runway.

Repairing a deliberately cratered airfield is a challenge even under the best of conditions. With no heavy equipment, asphalt, gravel, concrete, or engineers available, it seemed impossible. But no one should doubt the creativity and determination of the Green Berets. We accomplished the mission with assistance 
from one Air Force "RED HORSE" engineer sergeant, ${ }^{34}$ some talented U.S. Army mechanics, local labor, and Uzbek smugglers.

Our mechanics repaired an abandoned Soviet steamroller, while we used our operational fund to pay locals to haul smooth river rock from nearby creek beds. We then purchased 55-gallon drums of tar from smugglers. Under the supervision of the RED HORSE engineer, we filled the craters with river rock and then compacted the holes with the steamroller. We used an open fire to melt the tar, which we then poured over the rocks.

We repeated the process until the surface was level and we had enough runway to land a C-130 cargo plane. The Air Force Joint Terminal Attack Controllers were trained in air traffic control, and over the course of the next few weeks, we landed over 200 aircraft, including American C-17 and Russian IL-76 cargo jets. The Red Cross delivered humanitarian aid, which we helped distribute to the refugee camps, ameliorating some of their suffering and avoiding starvation.

In the weeks after the fall of Mazar-i-Sharif, Taliban resistance crumbled in city after city, including Kabul. By early December, the Taliban had ceased to exist as an effective fighting force or government. On December 22, an interim Afghan government was inaugurated in Kabul. ${ }^{35}$

Although it would be a decade before the United States finally found and killed Bin Ladin, and the Taliban would eventually reconstitute in the tribal areas of Pakistan, the men and women of Task Force Dagger and our brethren in the intelligence community had accomplished a stunning victory. We had achieved what many considered impossible: a force of several hundred Americans and disparate militias, backed by airpower, had outmaneuvered, outfought, and defeated the Taliban, driving them from power in a matter of weeks. In late January 2002, we handed over the mission of rebuilding Afghanistan to conventional forces and returned to Ft. Campbell the following month.

\section{Lessons learned}

\section{The lengthy Special Forces training is worth the investment}

We succeeded in an extremely difficult environment. Simply put, our training in the qualification course was spectacular. The Special Forces assessment and selection had identified the soldiers with the necessary determination, ingenuity, and adaptability. The qualification course, especially Robin Sage, had equipped us with the required skills to tackle all the situations we encountered. It is difficult to count the number of times that we remarked to each other, "This is just like Robin Sage!” Whether establishing rapport, dealing with a mercurial guerrilla chief, or sorting out factional rivalries, we had experienced it all in our training. In the case of ODC 53, individual skill and determination overcame a lack of prior collective training. The success as a collective organization was a testament to the Special Forces training and selection process.

\section{Logistics must be tested prior to combat}

Although we had great individual and collective training at the battalion level and lower, it relied on a fictional logistical concept and acquisition authorities that had never been truly exercised. When higher headquarters did participate in multi-echelon training, it focused on command and control, not unconventional warfare logistics with intercontinental supply lines. Had we participated in such an exercise, or tried to, we would have realized that the equipment and warehouses on which we expected to rely did not exist; the U.S. government did not have stockpiles of weapons and ammunition for guerrilla forces.

Additionally, we had never exercised logistical interoperability with other U.S. government departments and agencies. Consequently, we did not really understand the limits of their ability to support our operations. This led to an embarrassing incident after the Northern Alliance turned to Iran out of frustration 
with our inability to supply them with uniforms. We were shocked and dismayed when an Iranian C-130 landed bearing new police uniforms for the fledgling force.

While Special Forces operating in denied areas can sometimes rely on local procurement for resupply, this was not viable in the mountains of Afghanistan. Prior to our arrival, the Northern Alliance had exhausted their own supplies and were under pressure, barely subsisting, and losing territory to the better equipped and supplied Taliban forces. Consequently, our resupply of food, ammunition, equipment, and other supplies was wholly dependent on aerial delivery by parachute.

We once made the mistake of using the same drop zone twice in Mazar-i-Sharif, and we found ourselves in a foot race to the bundles with the locals. The drop contained a mixture of equipment for the U.S. teams and general supplies for the Northern Alliance, but there was no way to distinguish the bundles in the darkness. In the chaos, the local pillagers absconded with important equipment and supplies. Worse, Task Force Dagger could not provide a complete inventory of the equipment, making it nearly impossible to determine what had been lost. Thanks largely to luck, we determined that some locals had absconded with a box of equipment containing weapons sights and other components. Although the equipment was eventually recovered, it was a painful reminder of our logistical frailty.

Had we truly tested the logistics system in training, we might have realized that we did not maintain a sufficient system of operational "floats"—radios, weapons, and other types of equipment - to replace our operational losses or the legal authority to purchase police uniforms.

\section{The lack of war plans or war games negatively impacted operations}

There was a complete absence of plans to go to war in Afghanistan under any conditions, resulting in a massive whole-of-government crisis planning after 9/11. Our diplomats negotiated basing rights and authorities on the fly, causing delays and adding uncertainty to our planning efforts. The crisis planning also meant that parallel planning was initiated without the benefit of war gaming, synchronization, deconfliction, and integration that would normally occur in sequential planning.

The consequences of the highly compressed planning timeline were significant. For example, even though the Taliban did not pose a real threat to U.S. air superiority, the Air Force planners nonetheless chose to destroy the runway at Mazar-i-Sharif because that is what they always do. Even a single war game conducted prior would have shown this was unnecessary.

\section{Command and control must be rigorously designed and tested in peacetime}

An effective command and control system is essential for success in a multi-dimensional, joint (multiservice), and combined (multinational) combat environment. This conflict, however, exposed a significant disconnect between our doctrine and peacetime organization and the demands of expeditionary warfare. For various reasons, we abandoned our Army and joint doctrine regarding command and control in several important ways. In the middle of a crisis, we created command and control structures and relationships with which we had never experimented in peacetime, including the ODCs. The combined staffs had not trained together and had no standing operating procedures.

Moreover, since the units involved were not designed to support either the new structures or 24-hour operations, commanders had to rely on large numbers of individual augmentees. Most of these augmentees had little or no familiarity with the unconventional warfare mission, the units involved, the commanders, or the environment. They were nevertheless called on to perform critical staff and liaison functions. These hybrid organizations effectively eliminated multiple levels of command, destroyed unit integrity, and left the ad hoc Task Force Dagger staff with an overwhelming span of control. All of this reflected a combination of outdated doctrine and faulty assumptions about the strategic environment and a failure to rigorously design, test, and evaluate our command and control structures in peacetime. 


\section{Notes}

1 George W. Bush, Statement by the President in His Address to the Nation (Washington, DC: White House, 2001).

2 Leigh Neville, Special Operations Forces in Afghanistan (Oxford: Osprey, 2008), 8.

3 See, for example, Center for Military History, Operation Enduring Freedom: October 2001-March 2002 (Fort McNair: Center of Military History, no date), 12.

4 Gary Berntsen and Ralph Pezzullo, Jawbreaker: The Attack on Bin Laden and al-Qaeda (New York: Crown, 2005), 312.

5 Usama bin Ladin escaped to Pakistan, and it would be a decade before he was finally found and killed by the United States.

6 Joint Chiefs of Staff, Special Operations, JP 3-05 (Washington, DC: Joint Chiefs of Staff, 2011), II-9.

7 See, for example, Joint Chiefs of Staff, Doctrine for Joint Special Operations, JP 3-05 (Washington, DC: Joint Chiefs of Staff, 1998), II-6.

8 Special Forces soldiers are commonly referred to as "Green Berets" for the distinctive headgear that they are awarded upon completing the long and arduous Special Forces Qualification Course.

9 Two examples of special skills training include military free fall parachuting or underwater operations.

10 Mark Price, "Unconventional Warfare Training Being Staged in 21 North Carolina Counties," Charlotte Observer, August 21, 2019, www.charlotteobserver.com/news/local/article234211482.html.

11 Francis J. Kelly, U.S. Army Special Forces, 1961-1971 (Washington, DC: Department of the Army, 2004).

12 The Green Berets, Rambo, The Deer Hunter, and Apocalypse Now portrayed Green Berets as rogues at best and renegade, mentally unstable killers at worst.

13 "5th Special Forces Group (Airborne) History," U.S. Army Special Operations Command, accessed October 15, 2020, www.soc.mil/USASFC/Groups/5th/5thSFGHistory.html\#: :text=The $\% 205$ th\%20SFG\%20(A)\%20added, and\%20returned\%20in\%20April\%201991.

14 It was called Operation PROVIDE COMFORT. See "10th SFG(A) History," U.S. Army Special Operations Command, accessed October 15, 2020, www.soc.mil/USASFC/Groups/10th/history.html.

15 "5th Special Forces Group (Airborne) History," U.S. Army Special Operations Command.

16 Micah Zenko, Between Threats and War: Discrete Military Operations in the Post-Cold Era (Stanford: Stanford University Press, 2010), 66.

17 White House, A National Security Strategy for a New Century (Washington, DC: White House, 1999).

18 Ibid.

19 James Bennet, "U.S. Cruise Missiles Strike Sudan and Afghan Targets Tied to Terrorist Network," New York Times, August 21, 1998, www.nytimes.com/1998/08/21/world/us-fury-2-continents-overview-us-cruise-missiles-strikesudan-afghan-targets.html.

20 “Taliban Again Refuses to Turn Over Bin Laden," Associated Press, October 2, 2001, www.nytimes.com/2001/10/02/ international/taliban-again-refuses-to-turn-over-bin-laden.html.

21 Joint Chiefs of Staff, Doctrine for Joint Special Operations.

22 Charles H. Briscoe et al., Weapon of Choice: U.S. Army Special Forces in Afghanistan (Fort Leavenworth: Combat Studies Institute Press, 2003), 41.

23 Department of the Army, Special Forces Detachment Mission Planning Guide (Washington, DC: Department of the Army, 2012), 2.

24 C.J. Chivers, "2nd Wave of Troops Arrives in Uzbekistan,” New York Times, October 8, 2001, https://movies2. nytimes.com/2001/10/08/international/asia/08UZBE.html.

25 Patrick E. Tyler, "U.S. and Britain Strike Afghanistan, Aiming at Bases and Terrorist Camps; Bush Warns 'Taliban Will Pay a Price'," New York Times, October 8, 2001, www.nytimes.com/2001/10/08/world/nation-challengedattack-us-britain-strike-afghanistan-aiming-bases-terrorist.html.

26 "U.S. Special Operations Troops in Commando Raid," CNN, October 22, 2001, www.cnn.com/2001/WORLD/ asiapcf/central/10/19/ret.afghan.attacks/index.html.

27 Neville, SOF in Afghanistan, 11-14.

28 This map appears in Operation Enduring Freedom (Washington, DC: Center of Military History, no date), 9, https:// history.army.mil/html/books/070/70-83/cmhPub_70-83.pdf.

29 The Army's Standard Audiovisual Services Supplement (SAV SER SUP).

30 A jinga truck is a highly decorated cargo truck common in South Asia.

31 Richard A. Serrano, "Detainees Describe CIA Agent's Slaying," Los Angeles Times, December 8, 2004, www. latimes.com/archives/la-xpm-2004-dec-08-fg-prison8-story.html.

32 Carlotta Gall, "A Nation Challenged: Mazar-i-Sharif; U.S. Bomb Wounds G.I.'s as Battle Rages at Fort," New York Times, November 27, 2001, www.nytimes.com/2001/11/27/world/a-nation-challenged-mazar-i-sharif-usbomb-wounds-gi-s-as-battle-rages-at-fort.html. 
33 Katharine Q. Seelye, "Regretful Lindh Gets 20 Years in Taliban Case," New York Times, October 5, 2002 , www. nytimes.com/2002/10/05/us/threats-responses-american-taliban-regretful-lindh-gets-20-years-taliban-case.html.

34 The U.S. Air Force Rapid Engineer Deployable Heavy Operational Repair Squadron Engineer (RED HORSE) squadrons are "civil engineering SWAT teams." See Peter Grier, "The RED HORSE Way," Air Force Magazine, February 1, 2003, www.airforcemag.com/article/0203redhorse/.

35 "New Afghan Government Takes Control," ABC News, December 22, 2001, https://abcnews.go.com/Inter national/story? $\mathrm{id}=80300 \&$ page $=1$. 